The work of Prof. Weidenreich, more especially with the supplement of the cultural study of the contents of the palrolithic cave at Choukoutien, by W. C. Pei, offers too many points of interest for detailed comment here. One matter of special moment is the inference he draws that the important body of knowledge which has been derived from the specimens of Sinanthropus calls for " $a$ radical transformation of our conceptions of the problem of mankind", and he then proceeds to the significant conclusion that while human development has been orthogenetic, it has also been polycentric, certain consequences following logically upon this as affect. ing the mode of that development, in which Lamarckian and Darwinian conceptions are set aside as unim. portant in favour of an evolutionary progressive development of the type. At the samo time, his remarkable diagnosis of three racial types-Melanesian, Eskimoid and Mongoloid-in a single and small palæolithic population at so early a date is scarcely less significant for the further development of racial theory at large. Mr. Pei's cultural study of this same palæolithic population affords a view of its technological capacity which is little less than surprising. This is also, bo it noted, the first site in China on which cultural material of palæolithic age and human skeletal remains have been found in association.

\section{Universities and Government Grants}

IT is generally known the Government grants to the universities of Great Britain have been stabilized for a limited period from the beginning of the War. As that timo approaches its end, the Government and the University Grants Committee will be faced with a difficult task. The incessant call for economy at this time of stress must be heeded. No sum that can be saved, however small it may be, is negligible in the present circumstances; indeed it may be in the multitude of minor economies that the best hope lies. Nevertheless, in the matter of the universities, great caution and careful scrutiny will bo necessary. Any move which curtails the efficiency of the universities in the discharge of their duties would be sharply criticized. It will readily bo granted that the undergraduate population of the universities has decreased substantially, and national service has also claimed a varying proportion of the teaching and supervisory staffs. Teaching and research must, however, still go on. Apart from present needs, there is the future to consider. When the time comes for reconstruction, the universities must bo ready to expand rapidly and to play their part in building up the new order. This they can do only if they retain their efficiency throughout the days of wartime activity. The task of those in authority will bo to satisfy present needs and also to enable the universities to meet their obligations to the future.

\section{British Social Hygiene Council}

IT has been found impossible to continue meetings of the full Educational Advisory Board of the British Social Hygiene Council during the War. A repre- sentative Emergency Committee has been formed, howrever, and held its first meeting on December 19 at Tavistock House, London, W.C.1. It was decided that the long-term policy of stimulating the development of biological education should bo maintained so far as is possible. The possibilities of educational activities are to be explored on a regional basis; particular attention is to be clirected towards pro. viding short courses of lectures and talks for youth leaders, adolescents and men and women in the military forces. Tho development of biological education in tho Colonies is being continued and negotia. tions for the production of text-books of biology for use in schools in East Africa should soon be com. pleted. Tentativo inquiries are also being mado to determino tho possibilities of holding a Summer School for teachers, if circumstances pormit.

\section{Dendrochronology in the Eastern United States}

THE dream of the archeologist, for whom from the nature of his material an absolute chronology is rarely available, has been the attainment of a system of dating which should be universally valid; but diversity of conditions, as a rule, precludes anything approaching certainty when attempts are made to apply any given method of time measurement outside a more or less restricted area. For this reason much interest is attached to attempts which are being mado to extend the tree-ring method of dating outside the south-western United States, where it has been applied with conspicuous success to the dating of Pueblo remains and structures. The first successful observations in the eastern United States are recorded by Prof. Charles J. Lyon, of Dartmouth College (Science, 90, 419; Nov. 3, 1939), who has compared the rings of virgin white pine felled by a hurricane in September 1938 at Wolfeboro, N.H., with buried logs of the same species uncovered in an excavation at the site of an ancient bridge abutment nearby. The skeleton plot method of Douglass gave the date of 1806 for the last ring formed in the trees used to build the bridge, a result said to be "very reasonable in the light of Wolfeboro history". Further, from North Sutton, N.H., thirty-nine miles south of this bridge, a record of white pine was obtained for a 260-year period, establishing a link with the buried logs in a 128-year overlap between the outer rings of the latter and the inner rings of the Sutton trees. Although not sufficient for a standard scale, yet this marks a beginning in the formulation of an efficient instrument for the eastern archrologist; but it is noted that the identification in detail is less perfect than in the south-west. Apart from the cross-check, however, the rings agreed with a number of entries of drought in a diary.

\section{History of Intensive Cultivation}

AN interesting historical review of progress in the production of early vegetables by methods of intensive cultivation has recently been issued by R. J. G. Hopp (J. Roy. Hort. Soc., 64, Pt. 2; Nov. 1939). The first record of forcing plants appears to bo in the time of the emperor Tiberius, when cucumbers 
were grown in boxes of dung and sheltered during cold days with thin plates of Lapis specularia. Lettuce is mentioned by Charlemagne, and in the time of Albertus Magnus (1193-1280) it was grown throughout the year. From the Norman invasion of England until the middle of the sixteenth century, gardening appears to have been very greatly subordinated by the political unrest. Its development in the serenteenth century was closely bound with the herbalists Gerard and Parkinson. The initiation of French gardening, involving the protection of early plants with glass cloches, appears to have been due to Jean de la Quintinye in the second half of the seventeenth century, and crops were then brought to maturity upon hotbeds. Joln Evelyn, John Woolridge and Prof. Bradley added their quota of horticultural development in the succeeding hundred years, to be followed by J. C. Loudon. French gardening declined in the later half of the nineteenth century, however, only to give place to the more workable and convenient methods of glasshouse culturo which provide our present supplies of extra-seasonal vegetables.

\section{A New Cyclotron}

THE cyclotron constructed in the workshop of the Physics Department of Purduo University, Indiana, is described in the November issue of the Journal of the Franklin Institute by the five members of the staff who designed it. So far as possible standard materials available in industry have been used in its construction. The magnet is of low carbon steel $3 \mathrm{~m}$. long and $2 \mathrm{~m}$. high, and the pole pieces of special shape $1 \mathrm{~m}$. diameter. The magnetizing coils are of thin copper tube through which cold water circulates. Each coil is square in section with side $30 \mathrm{~cm}$. The oscillator is of the tuned grid tuned plate type, of frequency $10.9 \mathrm{MIc}$., with neutralizing condensers. It takes 3 amperes at 8,500 volts. The chamber is of the Berkeley type with floor and top of steel plate $3 \mathrm{~cm}$. thick with special arrangements for controlling the bending due to external pressure, which has been found to increase the beam intensity. The ions are supplied by an arc near the centre of the cyclotron. The instrument yields 16.5 million volts for $\mathrm{He}^{+}+$ ions.

\section{The National Institute for Research in Dairying}

The annual report of the National Institute for Research in Dairying, Reading, covering the year ending September 30, 1938, has just been published; this seems an unnecessarily long delay. Develop. ments, administrative matters and changes in the staff are outlined, and a summary is given of the research work that has been carried out in the various departments. Among tho last named is an investigation in the Department of Physiology and Biochemistry on the nutritive value of sprayr-dried milk, roller-dried milk and evaporated milk. The biological values of the proteins, and the content of vitamin $A$ and of vitamin $C$ are much the same for all three products, but vitamin $B$ is much reduced in the evaporated milk--to half that present in the other two. The results show that properly dried milk retains to a remarkable extent the nutritive value of the raw product and that modern methods of spray drying yield a powder of high nutritional quality. An appeal is made for donations to meet the cost of new buildings which are urgently needed to reliove the acute congestion in the existing laboratories.

\section{International Society of Medical Hydrology}

A MEETIsG of the general purposes committee of the International Society of Medical Hydrology was held in London on November 17 last to deal with emergency measures made necessary by the War, and also by the death of the Society's chairman of council, Dr. E. P. Poulton. Dr. J. Barnes Burt was elected interim chairman of council, and four addi. tional vice-chairmen, all in countries 'neutral' in the present conflict, were appointed. It was further resolved that the cash balance remaining should be set aside for reconstruction of the Society after the War, and the general secretary was given indefinite leave of absence without pay and instructed to close the London office. The Society's address will be, until further notice, that of the honorary treasurer, Dr. G. D. Kersley, 6 The Circus, Bath.

\section{Medical Organizations of India}

Tue medical organizations of all-India are reviewed by Major-General Bradfield, director-general of the Indian Medical Service, in a volume of 658 pages entitled "An Indian Medical Review" (Government of India Press, New Delhi, 1938). Administrative organization and the medical profession and services, hospitals and nursing, maternity service and pharmacy, and medical education and research, aro all surveyed in the first 280 pages, the remainder of the book containing full statistics of hospitals, dispensaries and other medical institutions. This volume should prove a useful supplement to the "Annual Report of the Public Health Commissioner with the Government of India".

\section{The Night Sky in January}

Durisg this month, the night shortens in the latitude of London by 1 hour 10 minutes, reckoning from sunset to sunrise. The moon is new on January 9, and full on January 24. Occultations of stars by the moon include three stars of magnitude $3-4$ of the Hyades cluster which precedes Aldebaran. The disappearances as seen from Greenwich take place on January 20 as follows: $\delta$ Tauri at $21 \mathrm{~h} .37 \cdot 9 \mathrm{~m}$. at position angle $107^{\circ}$ from the north point of the moon's disk: 64 Tauri at $22 \mathrm{~h} .31 \cdot \mathrm{lm}$. at $142^{\circ}$ and 68 Tauri at $23 \mathrm{~h} .29 \cdot 0 \mathrm{~m}$. at $16^{\circ}$. On January 23 , $\lambda$ Geninorum $(3.6 \mathrm{~m}$.) is occulted at $20 \mathrm{~h} .20 .9 \mathrm{~m}$. at $121^{\circ}$. There is a fine array of planets in the evening sky-Venus, Mars, Jupiter and Saturn-whilst Uranus, a faint 6th magnitude object, is in Aries near the 6th magnitude star 53 Arietis. At the beginning of the month, MIars is overtaking Jupiter in the eastward shift of the two planets among the stars by about $\frac{1}{2}^{\circ}$ a day, and on January 7 at $15 \mathrm{~h}$. there is a conjunction, the geocentric distance between 